Meta

Journal des traducteurs

Translators' Journal

\title{
Advances in Research on Translator and Interpreter Training: A Review of Research articles in META
}

\section{Jun Pan, Honghua Wang et Jackie Xiu Yan}

Volume 60, numéro 2, août 2015

$60^{\mathrm{e}}$ anniversaire. Les horizons de la traduction : retour vers le futur $60^{\text {th }}$ Anniversary. Translation's Horizons: Back to the Future

60mo aniversario. Los horizontes de la traducción: regreso al futuro

URI : https://id.erudit.org/iderudit/1032898ar

DOI : https://doi.org/10.7202/1032898ar

Aller au sommaire du numéro

Éditeur(s)

Les Presses de l’Université de Montréal

ISSN

0026-0452 (imprimé)

1492-1421 (numérique)

Découvrir la revue

Citer ce document

Pan, J., Wang, H. \& Yan, J. X. (2015). Advances in Research on Translator and Interpreter Training: A Review of Research articles in META. Meta, 60(2),

347-347. https://doi.org/10.7202/1032898ar 


\title{
Advances in Research on Translator and Interpreter Training: A Review of Research articles in META
}

\author{
JUN PAN \\ Hong Kong Baptist University, Hong Kong \\ janicepan@hkbu.edu.hk \\ Honghua WANG \\ Jiangsu University, Zhenjiang, China \\ ansonwhh@gmail.comb \\ JACKIE XIU YAN \\ City University of Hong Kong, Hong Kong \\ ctjackie@cityu.edu.hkc
}

In his famous "map" of the discipline, Holmes (1972/1988) listed training as one of the three "applied" branches of Translation Studies. The subfield of research on translator and interpreter training has hence witnessed some rapid development, in particular since the establishment of the first batch of university-level training programmes in the last century (Caminade andPym 2001). In reviewing the development of research on translator and interpreter training, The Translators' Journal, META, provides a best platform, which has published a total of around one hundred articles on this theme since the new millennium. The present paper thus aims to look into the research topics and methodologies covered in these articles to help delineate the features of research on translator and interpreter training. Thematic analysis will be applied in the identification of research themes of each article. The resulting picture will show a multi-layer classification of research topics and methods (see Yan, Pan et al. 2013). The prominent studies in each topical and methodological category will be discussed. The paper will also include an analysis of the authorship and distribution of those research articles. The study will help to identify the trends in research on translator and interpreter training. Such a retrospective endeavor will help to provide directions for us in the future navigation of translation practice and research.

Dr. Jun Pan is an Assistant Professor in the Department of English Language and Literature at Hong Kong Baptist University. Her research interests include interpreter and translator training, interpreting and translation theory, and corpus-based interpreting/translation studies.

Dr. Honghua Wang is a lecturer in the English Department at Jiangsu University. Her research interests include translation studies, translator and interpreter training and second language acquisition.

Dr. Jackie Xiu Yan is an Associate Professor in the Department of Linguistics and Translation at City University of Hong Kong. Her research interests include applied linguistics, interpreter training, and translation studies. 